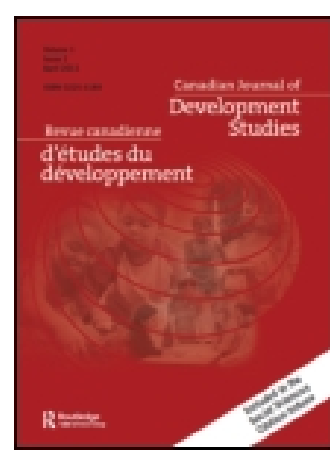

Canadian Journal of Development Studies/

Revue canadienne d\&apos;\&eacute;tudes du d\&eacute; veloppement

\title{
Trade, Transition Paths, and Sustainable Economies
}

\section{Patricia E. Perkins}

To cite this article: Patricia E. Perkins (1999) Trade, Transition Paths, and Sustainable Economies, Canadian Journal of Development Studies/Revue canadienne d\&apos;\&eacute;tudes du d\&eacute;veloppement, 20:3, 593-608, DOI: 10.1080/02255189.1999.9669856

To link to this article: https://doi.org/10.1080/02255189.1999.9669856

\section{曲 Published online: 24 Feb 2011.}

Submit your article to this journal $\sqsubset$

\section{山 Article views: 26}

Q View related articles $\square$ 


\title{
Trade, Transition Paths, and Sustainable Economies
}

\author{
Patricia E. Perkins
}

\begin{abstract}
The main criticisms of trade from a sustainability viewpoint are that it accelerates resource depletion and pollution, harms income distribution both locally and internationally, and undermines democratic institutions. After considering the relationship between trade and "sustainability," this paper discusses a number of feedback mechanisms which promote the kind of trade that is more sustainable - for the South as well as the North. The role of technological change, a model of the relationship between production and "sustaining services," data needs and research priorities are also discussed.
\end{abstract}

\begin{abstract}
Du point de vue écologique, on accuse le commerce d'avoir accéléré l'amoindrissement de ressources et la pollution, de nuire d la distribution des revenus aux niveaux local et international, et d'enfreiner les institutions démocratiques. Partant de la relation entre le commerce et la " durabilité ", cet article examine certains mécanismes qui induisent la promotion d'une autre forme de commerce qui serait durable autant au Sud qu'au Nord. L'article explore aussi le rôle de la transformation technologique, un modele de la relation entre la production et les services de soutien, les besoins et les priorités de telles recherches.
\end{abstract}

\section{INTRODUCTION}

International trade has been criticized on a number of grounds. It exacerbates local and global income-distribution inequalities; it distorts patterns of resource use and hastens resource depletion; and it changes the political calculus and saps democratic, local decision-making processes. These general

This paper has benefitted from a number of insightful comments by Hilkka Pietilä, Real Lavergne, Gerry Helleiner, Rohinton Medhora, and other participants in the conference Economics As If Developing Countries Mattered, in honour of Professor Gerry K. Helleiner, held October 23, 1998, at the University of Toronto.

Patricia E. Perkins is Associate Professor at the Faculty of Environmental Studies, York University. She teaches environmental and ecological economics. 
Canadian Journal of Development Studies objections to trade can be found in the literature dating back to Marco Polo and the trans-Saharan gold trade in the Dark Ages (Vilar, 1976; Ponting, 1991).

As the volume and value of world trade have increased, so too has the importance of trade's drawbacks, as dramatized by recent public opposition to the GATT, NAFTA and the MAI. Much of the current literature on globalization stresses the snowballing impetus of trade patterns controlled by multinational corporations which increasingly make global production decisions (that also affect consumption and resource depletion), with very little input from the political process in any jurisdiction. ${ }^{1}$ Points along the "positive-feedback loop" of globalization include advertising, increased consumer demand and waste, long-distance transport of goods, pollution, high profits, strategic political influence, reduced local institutional control, mechanization, reduced demand for labour, and centralized private decision-making. ${ }^{2}$

However, there are also "negative feedback loops" at work in the global trading system - processes which, like a thermostat, tend to keep trade in check when it threatens to get out of control, and to reduce trade's insalubrious effects on income distribution, resource depletion and local political systems. The economics of self-limiting systems is not well developed, but, flowing from work in ecology and biology, new theoretical approaches to understanding self-limited economic systems are becoming more widely known (Peet, 1992; Krugman, 1996; Magnusson and Ottosson, 1997; Leydesdorff and Van Den Besselaar, 1994).

The remainder of this paper addresses the working of negative economic feedback loops and their implications for the sustainability of world trade. After exploring what is meant by "sustainable" in the following section, we go on to discuss a number of specific feedback loops and return at the end of the paper to the question of how the transition to a more sustainable global trading system might come about.

\section{TRADE AND SUSTAINABILITY}

This section provides a very brief summary of the voluminous literature on the relationship between trade and "sustainability," as background for the discussion in later sections of the paper.

1. Global capital flows, which of course dwarf goods trade in monetary terms, have related but distinct effects and implications deserving of a separate analysis, which is not undertaken in this paper.

2. For an elaboration of the positive feedback cycle by which "the past and present degradation of nature impedes economic development in the future," see Altvater (1993). Arthur (1990) discusses other economic feedbacks. 
The idea of sustainability encompasses a number of components. Three elements stand out from the general critique of trade outlined above:

1. resource depletion, and the environmental effects of producing, distributing and consuming traded goods and services instead of local goods and services;

2. income distribution, or the effects on different social groups of their participation or non-participation in a global trading system;

3. political equilibrium, or the impact of trade on the institutional infrastructure of the countries involved.

Much of the literature on trade and environment focuses on the first of these elements, and concludes that the Ricardian efficiencies associated with trade lead to economic growth making possible environmental protection strategies such as pollution taxes and emissions control mechanisms. Natural resources are also used more efficiently via trade, it is argued: more economic benefit can be derived from a given level of resource throughput, with less pollution, when trade allows factors to be used efficiently. Because of technological change and substitution possibilities, resource depletion is not an important issue for some.

Dissenters in this discussion argue that trade skews incentives toward use of new natural resources and over-consumption rather than re-use of goods and materials, and that the beneficial environmental policy effects of trade-related economic growth are limited to a few kinds of pollution control in a few countries. Crucial global environmental questions, such as climate change and trade in toxic wastes, remain unaddressed. Unlimited resource substitution is not possible, due, among other things, to the laws of thermodynamics; trade contributes dramatically to the depletion of fossil fuels, by one estimate accounting for about an eighth of all fossil fuel use (Ekins, 1995).

Thus, even considering only the "environmental" effects of trade, opinions in the literature are quite mixed regarding trade's implications (Johnstone, 1995; Steininger, 1994; Daly and Goodland, 1992; Lang and Hines, 1993; Daly, 1993).

When social and political effects are added to the equation, the conclusions become much less sanguine. Income inequality within countries seems to increase with globalization, putting some people out of work in the North and stepping up competitive pressure on other workers in the South; income inequality is also increasing internationally, partly due to trade expansion, as the rich become better able to take advantage of global market opportunities (Van der Stichele, 1997; Krugman, 1995). According to United Nations statistics, the gap between the $10 \%$ richest and the $10 \%$ poorest of the world's population increased almost tenfold during the 1980s; between 1975 and 1990, the volume of world exports nearly doubled (Gill, 1995; French, 1993). Gender- 
Canadian

Journal of

Development Studies based inequality also increases with trade in many instances (Ward, 1990; Cameron, 1994; Cohen, 1992; Elson, 1993; Gabriel and Macdonald, 1996).

For some commentators, however, the most insidious effects of increasing trade are those on political institutions and the policy-making system. "Regulatory chill," reduced government revenues and provision of social and other services, less emphasis on enforcing environmental regulations, international competition for foreign direct investment, increased currency speculation and financial/monetary instability, and growing unanimity between corporate and government agendas are some of the aspects of this process (Campbell, 1993; Perkins, 1996b; Low, 1997).

From a thermodynamic viewpoint (in which global entropy unavoidably increases and can only be countered by use of solar radiation), trade can allow ecological constraints on economic growth to be avoided spatially, just as leaving mountains of waste behind for future generations avoids ecological constraints temporally (Rees and Wackernagel, 1994; Jackson, 1996). But the potential for such avoidance is absolutely limited, and "ecological limits turn into social limits and finally into barriers to economic rationality" (Altvater, 1993). The distinction between trade which allows entropy-shifting, and trade which does not, therefore becomes important in assessing its sustainability.

Another important issue is the implications of reduced trade for international equity. Even if the relative benefits of globalization for the South compared to those for the North are debatable, some Southern countries and groups within countries have undoubtedly benefitted absolutely from expanded world trade in recent decades. Furthermore, trade appears to be one of the few mechanisms available for distributing financial and material resources internationally. Positing that trade should be reduced on "sustainability" grounds is not ethical or tenable without some other mechanism in place for bringing about a more equitable world distribution of income than currently exists (Hudson, 1997).

Taking all the above considerations into account, we are left with the issue of how much trade is "sustainable." It seems clear that the stronger one's definition of "sustainability", the less trade is desirable (Perkins, 1997a). Moreover, far more than environmental impacts must be considered if true long-term sustainability of the economic (and hence the social and political) system is the goal. These trade-related effects include those at the local or community level, as well as at the national and global levels (Norgaard, 1995; Nozick, 1992).

In effect, the sort of trade which does no harm to a sustainable economy might be defined as follows: It is an exchange of goods or services across national or bioregional borders which involves and requires only renewable physical resources and energy supplies; does not exceed the natural generative and 
assimilative capacities of the ecosystems where it takes place; is engaged in freely and voluntarily by all (even indirect) participants; contributes to the potential, interest and diversity of people's lives without undermining their own productive abilities or independence; and has no deleterious effects on social structures, political institutions, culture or democracy in the areas involved.

In the next section, we will investigate the implications of this definition for the kinds of goods and services that might be traded in a sustainable economic system, and for technological change.

\section{TECHNOLOGICAL CHANGE AND GOOD TRADE}

What the preceding analysis of trade and sustainability points up is that knowledge of the particular goods and services traded, and how they are produced (by whom, under what working and living conditions, using what raw materials and production processes, etc). is crucially important to understanding whether their trade can be termed "sustainable." ${ }^{3}$ In other words, general statistics on the money value of trade overall are of little use for these purposes; more specific, detailed and "small-scale" information is needed.

We can, however, make a few general statements about the market-derived feedbacks conducive to a more sustainable trading system. First, the primary negative feedback in a competitive market system is price, whose rise induces a fall in the demand for the good in question, causing more of it to be available, causing the price to fall again, and so on. Insofar as the price of natural resources and energy is competitively set, price rises can induce technological change, reducing the demand for increasingly scarce resources, thus perhaps causing production processes - and therefore trade in the goods involved - to become more sustainable. (If additional pollution or resource depletion of other kinds results from the new processes used, this could however, counteract the effect of the reduced throughput.) Likewise, to the extent that negative "externalities" such as pollution or labour exploitation can be internalized in competitive markets ( for example, through well-enforced government taxation or other policies), the effect will be to make production processes and trade in the resulting goods more sustainable than before.

3. Environmentalists' dismay about the WTO dispute resolution procedures, which permit "product-related" but not "process-related" discrimination in trade policy, is founded in this principle: from a sustainability perspective, the appropriateness of production processes is vitally important. 
Canadian

Journal of

Development Studies

There is far-reaching potential for progressive technological change to lead to reduced material and energy throughput in production processes, more ecological transportation methods, improved worker safety, education, international distribution of information, and other benefits. In fact, in many instances, "green" technological knowledge is far ahead of the ability of markets and societies to make use of it. This points up another general characteristic of markets with regard to more sustainable trade: in many cases they are NOT competitive, and are not particularly adept at accommodating the kinds of changes in production processes, and social and distributional equity, that are desirable from a sustainability point of view - even when these are cheaper, more efficient and proven via pilot projects (Hubbard and Fong, 1995; Panayotou and Zinnes, 1994).

Consumer demand, however, is a strong motivator for progressive environmental and social movement by corporations, even in imperfectly competitive industries. Especially in Europe, "green" consumer pressure has brought about many progressive changes in production processes and trade patterns."

Two negative feedback processes which facilitate the development and adoption of "green" and socially positive technological change in the face of globalization are the following:

First, the spread and democratization of scientific knowledge, via the Internet and other means, allows technological solutions to local problems to be developed by the people who need them, in response to their own resource constraints, social situations, and awareness of global potentialities, as well as inequities. ${ }^{5}$ In other words, globalization leads to the international dissemination of ideas that can permit some people to remove themselves from the global market if it does not meet their needs. Smaller-scale and more appropriate technological development, and the use of "green" technologies developed in one place by people in other places, can result.

Second, the globalization of markets also makes consumer boycotts, "whistle-blower" actions, and international campaigns for corporate responsibility much more effective and powerful than they would be in segmented national markets. Environmental, health, and human rights concerns arising in one place can receive international attention, and large firms may devote

4. Examples include the high demand for recycled paper and vegetable-dyed textiles in Europe, as well as the package-recycling systems supported by taxpayers and consumers there.

5. For example, in The Netherlands, community groups' science research needs are addressed through a network of "Science Shops" run by volunteer university researchers; in Peru, PRATEC (the Andean Project for Peasant Technologies) develops indigenous blends of cultural and technical solutions to local agricultural problems resulting from the Green Revolution. See Sciove (1997); Appfel-Marglin and Addelson (1997). 
extra attention to product testing, worker safety and pollution control to ensure that they do not receive uncontrollable negative publicity. ${ }^{6}$

Both these mechanisms, while impelled by the momentum of globalization, have the effect of generating beneficial changes in both production processes and the social effects of production, from a sustainability viewpoint. They are effective primarily because they cause changes in international trade patterns, generally in the sense of reducing the kind of trade which is most harmful to sustainable economies.

As the global implications of fossil fuel and other resource depletion, climate change, biotechnology risks, and toxic waste generation become clearer (or as crisis situations bring these dangers into focus for many people), there will be increasing pressure for the kind of technological change that will allow reduced material throughput with no loss in use-value of the goods produced. This redefinition of the meaning of productivity growth - instead of more output per unit input of a factor, more use (e.g. longer product life, or more consumer satisfaction) per unit of output produced and sold - leads organically to a second redefinition, of the meaning of consumer satisfaction itself. Instead of positing insatiability, and equating greater consumer satisfaction with higher consumption as measured in dollars spent, economists must continue to explore and theorize the non-material, and indeed the non-consumption, components of human satisfaction. ${ }^{7}$

Meaningful work is clearly a primary determinant of human satisfaction. Because most "green" production processes require more labour and less capital than traditional production processes (since they use less energy and fewer machines, and take more effort to reduce wastes), they often have the side effect of creating more jobs - which is a crucial need in both North and South. ${ }^{8}$ This is another negative feedback in the global system: for both ecological and social reasons, the limit to mechanization of production processes is becoming apparent; a switch to greener and more labour intensive production processes implies positive effects both environmentally and socially.

6. Examples include the Nestle boycott in protest of infant formula marketing practices in the South, the Nike boycott in protest of exploitative labour practices in Asia, negative publicity for Dow following the Bhopal incident, protests in Europe against Canadian forestry practices and the seal hunt, boycotts on the use of tropical hardwoods, etc.

7. Examples of this new kind of theorizing include Elmar Altvater's redefinition of usevalue as "lower entropy with higher order" (Altvater, 1993); Richard Norgaard's inclusion of cultural values, diversity and sufficiency as elements of consumer satisfaction (Norgaard, 1994); and Gandhian economists' "doctrine of non-possession" (Diwan and Lutz, 1985).

8. The kinds of work created, whether it is paid or unpaid work, and who does it, are all important distributional issues which arise in this connection. See Macgregor, 1996. 
600

Fine, but what is the real potential of all these feedback mechanisms actually to reduce the overall volume of world trade? And would that be a good thing? Would it not harm those in both South and North who are already the worst off? The following section takes up these important questions.

Canadian

Journal of

Development Studies

\section{TRADE VOLUMES AND IMPACTS}

Before addressing their macro-potential and implications, let us summarize the various kinds of sustainability-related trade-limiting mechanisms:

1. Rising prices for some resources and goods, caused by limited physical supplies, by rising transport costs, and by environmental policies aimed at internalizing externalities, can make domestically produced, "greener" and/or more labour intensive substitutes competitive, thus reducing trade.

2. Growing instability in world markets - resulting from the effects of weather, natural disasters, and climate change in agriculture, fisheries, insurance, and other sectors - can disrupt and reduce trade. Financial market and currency instability, and poverty, are interrelated phenomena (Blaikie, 1994; Smith, 1996). Trade volumes drop in the short term owing to transport and distribution disruptions, and in the long term as people seek more stable, controllable, and diverse sources of supply that are closer to home, and cheaper in local currency.

3. Industrial ecology initiatives, designed to capture higher economic value per unit of throughput and reduce wastes by assembling production chains where each firm uses the previous firm's output or waste by product as its own input, are spreading. Such ecological "economies of proximity" can more than compensate for economies of scale elsewhere and bring production and jobs closer to final markets (Socolow, Andrews, Berkhout, and Thomas, 1994).

4. Local, community-centred economies (grounded, for example, in LETS systems, community-shared agriculture, energy-saving construction projects, co-operatives, and selective consumer action) are growing in many places. These provide participants with alternatives to trade and dependence on global markets.9 (Perkins, 1996a; Douthwaite, 1996; Nozick, 1992; Lang and Hines, 1993).

5. Moral and ethical limitations on consumption, especially of foreign goods, such as the Gandhian ideas noted above (Huq, 1985; Shiva, 1993) are echoed in growing Northern "green consumer" and "voluntary sim-

9. LETS stands for Local Exchange Trading System. 
plicity" movements which emphasize goods' provenance, production methods and durability. In reducing consumption overall and stressing local production, these movements reduce trade as well.

6. Institutional and regulatory restrictions on trade of certain kinds are also increasing. These include the Montreal Protocol limitations on trade in ozone-depleting substances, the CITES bans on trade in endangered species and their products - both of which are expressly permitted to supersede NAFTA - the WTO standoff with the U.S. over imports of

Trade and Sustainable Economies dolphin-unfriendly tuna, OECD "voluntary measures" designed to reduce the production and export of goods made with harmful materials such as lead and cadmium, and international efforts to limit trade in toxic wastes, nuclear materials, some armaments, untested or dangerous medicines and pesticides, and other "bads" (New York Times, 1996; Jackson, 1993; Perkins, 1994).

7. Services are assuming an ever-larger share of GNP in many economies, and are harder than goods to trade (Krugman, 1991).

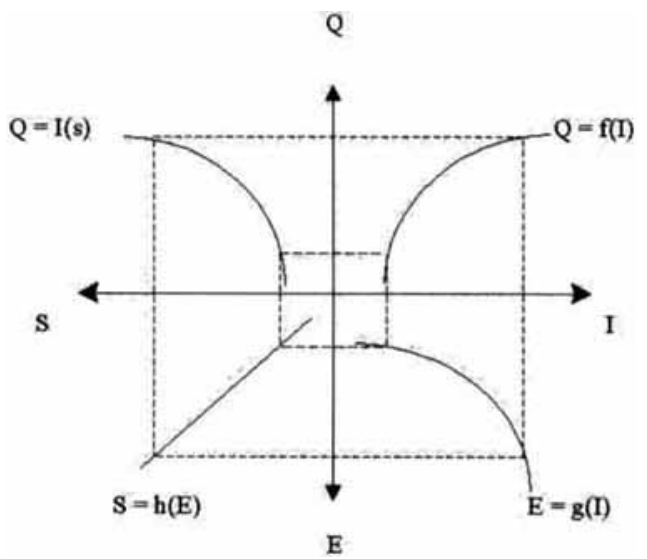

Figure 1

A model which captures the effects of these mechanisms, relating production and consumption to the environmental, physical and social "sustaining services" on which the whole economy depends, has been proposed by Sabine O'Hara (Figure 1). In this model, $Q$ is the level of output, I stands for the traditional inputs into the productive process (labour, capital, and materials), $E$ stands for emissions, and $S$ stands for the sustaining services, both environ- 
Canadian

Jourmal of

Development Studies mental and social, which are required for production to take place. Output $Q$ is a function of inputs I, but also of sustaining services $\mathrm{S}$. Emissions grow as input use increases, but this causes damage to sustaining services that eventually has a limiting effect on output.

In effect, by depicting production quantity as a trade-off between materials throughput and damage to sustaining services via emission rates, this model gives a conceptual framework for estimating the optimum scale of the economy as a whole - albeit an optimum which is continually changing and evolving. It is sustaining services which close the model and whose erosion, in a negative feedback process, sets a limit on the market's expansion ${ }^{10}$ (O'Hara, 1997).

While this model was designed to address limits on production overall and not trade per se, it can easily be adapted to the related question of how trade itself can damage global "sustaining services." The implication is that unsustainable patterns of economic growth or trade may cause catastrophic and sudden drop-offs in global "sustaining services" - crises which use of this kind of model could potentially help to predict and forestall.

Whether the feedbacks listed above are actually causing reductions in trade overall is a matter for empirical investigation, which as far as I know has not been done. More important than these mechanisms' general effects on trade volumes, however, are their implications for the kinds of goods traded. As previously noted, trade that is more sustainable than at present will involve "greener" goods, produced using "greener" production methods by workers who live "greener" lives. The effect of all the mechanisms listed above is to shift overall production and trade in a more sustainable direction.

For workers and consumers in the South as well as the North, this shift is a positive thing. Notes Enrique Leff with regard to Mexico, "emergent environmental movements are internalizing the environmental conditions for sustainable production, based on the productivity of nature and the values of social equity and cultural diversity. As these movements deploy their power strategies to construct an alternative productive rationality, resources will be removed from the sphere of market economy, imposing a limit to the capitalization of nature" (Leff, 1996; Leff, 1995).

While a generalized "de-linking" from global markets is not frequently espoused from a Southern perspective, perhaps owing to the need for economic growth as an engine of international income redistribution, a few Southern theorists have extensively explored and advocated development

10. This emphasis on the foundation conditions which make economic processes possible is a central theme of feminist ecological economics. 
strategies focusing on national self-reliance in the South. They include Clive Thomas, Samir Amin, Raul Prebisch, and Osvaldo Sunkel (Hudson, 1997; see also Khor, 1993). Trade-based, export-oriented policies can certainly be problematic, in practice if not in theory, but they have brought absolute benefits for many in the South. As noted above, a weakness of much Northern literature on local economies and de-linking, including the work of Herman Daly, is that it fails to propose a detailed alternative strategy for bringing about international justice in the distribution of economic, social and ecological conditions.

The essence of such an alternative strategy lies in distinguishing among goods and the processes used to produce them, from a sustainability perspective. An apple, a kilo of sugar, or a sewing machine may each have very different economic, social and ecological effects depending on where it comes from and how it is produced. Trade's impact and development potential, in the South as in the North, depend crucially on these sorts of factors. It is not trade itself which is bad for development, or for sustainability; it is the wrong kind of trade (Perkins, 1997a).

\section{BAD TRADE AND GOOD TRADE}

How, then, to limit "bad trade" - that which increases throughput, pollutes, exploits workers, exacerbates distributional inequities and harms "community"?11

If we are right about the nascent feedback mechanisms operating in the economy, the patterns of what is traded may gradually shift away from "bads." This shift will be driven by a combination of price changes, financial and ecological crises, social and environmental policy innovation, consumer demand, local economic development and de-linking, technological and organizational change, and political pressure. Whether it will be fast enough and effective enough to forestall social and ecological disaster remains to be seen. But the key to understanding this process lies in deconstructing the category "trade" into its component parts, from the standpoint of its sustainability implications. This involves much more than just the traded goods themselves; the whole nexus of social, ecological and political conditions surrounding their production is also important.

11. Some authors advocate institutional approaches to limiting "bad trade", via targeted protectionism, stronger international environmental agreements, limits on international financial transfers, and other types of regulations. See Perkins (1997b), Daly and Cobb (1989), Lang and Hines (1993), Altvater (1993), and Tobin (1995). 
Canadian

Jourmal of

Development Studies

In order to conduct research, make policy recommendations, and theorize about these matters, academics and educators need accurate, specific data on many aspects of trade flows. Although this information is usually not being gathered by national public institutions, generalizations based on the aggregated types of trade data which are available are unhelpful, as we have noted.

However, it is local, not national, policy initiatives, and community-based or non-market actions, which are central to many of the feedback mechanisms discussed above. Usually these measures are taken by people who are well aware of the specifics of trade's impact on their communities, and of the reasons for that impact. In the Toronto area, for example, FTA- and NAFTArelated job losses caused by factory closings in the early 1990s led to an upsurge of interest in the Toronto LETS, which allowed people with reduced money incomes to continue to be economically active while building the institutions of a less trade dependent "local economy." What this indicates is that the specific information needed to analyze trade's effects is available at the local level, for those who look. There is growing theoretical support for such disaggregated, specific and contextual study of economic processes. ${ }^{12}$

\section{CONCLUSION}

Transition paths exist toward more sustainable economies which include trade. The metaphor of "negative feedbacks" is a useful way to think of these paths, because they act like thermostats, are driven by the same processes as globalization but countering its worst tendencies. Such feedback mechanisms include fairly traditional economic processes like price-related demand shifts, the growth of the service sector, and changes in demand patterns, as well as relatively novel phenomena such as industrial ecology, LETS, and technological democratization.

A crucial conclusion is that trade's ramifications for sustainability cannot be tracked without knowledge of the particular goods being traded, their production processes, and the social and environmental conditions under which they are produced.

New theoretical approaches that are evolving for analyzing and understanding these trends include the redefinition of productivity to include usevalue and entropy; modelling the central role of "sustaining services" in

12. See the work of Paul Krugman, Richard Norgaard, and Amartya Sen; also O'Hara (1997), Funtowicz and Ravetz (1994). 
limiting output growth; and acceptance of the need for decentralized and specific, contextual analysis of trade and other economic patterns.

\section{REFERENCES}

Altvater, E., The Future of the Market, London, New York: Verso, 1993.

Appfel-Marglin, F. and K.P. Addelson, "Mutual Learning", in T. Schroyer ed., A World That Works, New York, Bootstrap Press, 1997.

Arthur, B., "Positive Feedbacks in the Economy," Scientific American, No. 262, February 1990.

Blaikie, P., T. Cannon, I. Davis and B. Wisner, At Risk: Natural Hazards, People's Vulnerability, and Disasters, London/New York, Routledge, 1994.

Cameron, B., "The Impact of Free Trade on Women's Employment," York University, 1994.

Campbell, B., "Globalization, Trade Agreements, and Sustainability," in Canadian Environmental Law Association, The Environmental Implications of Trade Agreements, Toronto, Ontario Ministry of Environment and Energy, 1993.

Cohen, M.G., "New International Trade Agreements: Their Reactionary Role in Creating Markets and Retarding Social Welfare," in I. Bakker, ed., Rethinking Restructuring: Gender and Change in Canada, Toronto, University of Toronto Press, 1996.

Cohen, M., "The Implications of Economic Restructuring for Women: The Canadian Situation," Paper presented at the conference on Canada in Transition, at the Autonomous University of Mexico, Mexico City, November 27, 1992.

Daly, H., "Elements of Environmental Macro Economics," in Robert Costanza, Ecological Economics, New York, Columbia University Press, 1991.

Daly, H. and R. Goodland, "An Ecological-Economic Assessment of Deregulation of International Commerce Under GATT", Washington, World Bank, Environment Department, 1992.

Daly, H. E. and J. Cobb Jr., For the Common Good: Redirecting the Economy Toward Community, the Environment, and a Sustainable Future, Beacon Press, 1989.

Daly, H., " From Adjustment to Sustainable Development. The Obstacle of Free Trade," in The Case Against Free Trade, GATT, NAFTA, and the Globalization of Corporate Power, San Francisco/Berkeley, CA, Earth Island Press/North Atlantic Books, 1993.

Diwan, R. and M. Lutz, eds., Essays in Gandhian Economics, New Delhi, Gandhi Peace Foundation, 1985.

Douthwaite, R., Short Circuit: Strengthening Local Economies for Security in an Unstable World, Foxhole, UK, Green Books, 1996.

Trade and Sustainable Economies 
Ekins, P., 'Trading Off the Future: Making World Trade Environmentally Sustainable," in R. Krishnan, J. Harris and N. Goodwin, A Survey of Ecological Economics, Washington, DC, Island Press, 1995.

Elson, D., "Gender-Aware Analysis and Development Economics," Journal of International Development, vol. 5, no. 2, 1993.

Canadian Journal of Development Studies
French, H., "Costly Tradeoffs: Reconciling Trade and the Environment," Washington, WorldWatch Institute, Paper No. 113, March 1993.

Funtowicz, S. and J.R. Ravetz, "The Worth of a Songbird: Ecological Economics as a Post-Normal Science," Ecological Economics, vol. 10, p. 197-207, August 1994.

Gabriel, C. and L. Macdonald, "NAFTA and Economic Restructuring: Some Gender and Race Implications," in I. Bakker, ed., Rethinking Restructuring: Gender and Change in Canada, Toronto, University of Toronto Press, 1996.

Gill, S., "Theorizing the Interregnum: The Double Movement and Global Politics in the 1990s," in B. Hettne, ed., International Political Economy: Understanding Global Disorder, Halifax, Fernwood Press, 1995.

Hubbard, A. and C. Fong, Community Energy Workbook: A Guide to Building a Sustainable Economy, Snowmass, CO, Rocky Mountain Institute, 1995.

Hudson, M., "Border Crossings: Linking Local and Global Struggles for Sustainable Livelihood Through Alternative Trade," MES Thesis, York University, Faculty of Environmental Studies, 1997.

Huq, A.M., "The Doctrine of International Trade: A Gandhian Perspective," in R. Diwan and M. Lutz, eds., Essays in Gandhian Economics, New Delhi, Gandhi Peace Foundation, 1985.

Jackson, T., Material Concerns: Pollution, Profit and Quality of Life, London/New York, Routledge, 1996.

Jackson, J.H., "World Trade Rules and Environmental Policies: Congruence or Conflict?" in D. Zaelke, P. Orbuch and R.F. Housman, eds., Trade and the Environment, Washington, DC/Covelo, CA, Island Press, 1993.

Johnstone, N., "Trade Liberalisation, Economic Specialization, and the Environment," Ecological Economics, vol. 14, no. 3, p. 165-173, 1995.

Khor, M., " Free Trade and the Third World," in Ralph Nader et al., eds., The Case Against Free Trade, San Francisco/Berkeley, Earth Island Press, 1993.

Krugman, P., Geography and Trade, Cambridge, MA, MIT Press, 1991.

"Globalization and the Inequality of Nations," Cambridge, MA, National Bureau of Economic Research, Working Paper No. 5098, April 1995.

,The Self-Organizing Economy, Cambridge, MA, Blackwell, 1996.

Lang, T. and C. Hines, The New Protectionism: Protecting the Future Against Free Trade, London, Earthscan Publications, 1993.

Leff, E., Green Production, New York/London, Guilford Press, 1995. 
“From Ecological Economics to Productive Ecology: Perspectives on Sustainable Development from the South," in Getting Down to Earth: Practical Applications of Ecological Economics, Washington, DC, Island Press, 1996.

Leydesdorff, L. and P. Van Den Besselaar eds., Evolutionary Economics and Chaos Theory, New York, St. Martin's Press, 1994.

Low, M., "Representation Unbound: Globalization and Democracy," in Kevin R. Cox, ed., Spaces of Globalization: Reasserting the Power of the Local, New York/London, Guilford Press, p. 245-274, 1997.

Macgregor, S., "Sustainable for Whom? Feminist Perspectives on Sustainability," Unpublished paper, York University, Faculty of Environmental Studies, 1996.

Magnusson, L. and J. Ottosson eds., Evolutionary Economics and Path Dependence, Cheltenham, UK/Brookfield, US: Edward Elgar, 1997.

New York Times, "Rich Nations Urge Action to Cut Danger From Lead," The New York Times, February 23, 1996.

Norgaard, R., "Sustainable Development: A Co-Evolutionary View," in Rajaram Krishnan, J.M. Harris, and N. Goodwin, eds., A Survey of Ecological Economics, Washington, DC/Covelo, CA, Island Press, 1995.

Nozick, M., No Place Like Home: Building Sustainable Communities, Ottawa, Canadian Council on Social Development, 1992.

O'Hara, S., "Toward a Sustaining Production Theory," Ecological Economics, vol. 20, no. 2, p. 141-154, February 1997.

Panayotou, T. and C. Zinnes, "Free-Lunch Economics for Industrial Ecologists," in Socolow, R., C. Andrews, F. Berkhout and V. Thomas, eds., Industrial Ecology and Global Change, Cambridge, UK, Cambridge University Press, 1994.

Peet, J., Energy and the Ecological Economics of Sustainability, Washington DC/Covelo, CA, Island Press, 1992.

Perkins, P.E., "NAFTA and the Future of Environmental Regulation: A View From Ontario," unpublished paper, 1994.

" Building Communities to Limit Trade," Alternatives Joumal January 1996a.

"NAFTA and Environmental Regulation: The Ontario Experience," unpublished paper, $1996 \mathrm{~b}$.

"What Is Sustainable Trade?" in Dev Gupta and Nanda Choudhry, eds., Studies in Globalization and Development, Dordrecht, Kluwer, 1997a.

" "Trade and Ecology: Local Economies and Global Sustainability," unpublished paper, $1997 \mathrm{~b}$.

Ponting, C., A Green History of the World, New York, Penguin Books, 1991.

Prugh, T., Natural Capital and Human Economic Survival Solomons, MD, ISEE Press, 1995. 
Rees, W., and M. Wackernagel, " Ecological Footprints and Appropriated Carrying Capacity," in A.M. Jansson et al., eds., Investing in Natural Capital: The Ecological Economics Approach to Sustainability, Washington, DC, Island Press, 1994.

Schroyer, T., ed., A World That Works, New York: Bootstrap Press, 1997.

Canadian Journal of Development Studies
Sclove, R., "Research By the People," in Schroyer, T. ed., A World That Works, New York, Bootstrap Press, 1997.

Shiva, V., "The Greening of the Global Reach," in W. Sachs, ed., Global Ecology: A New Arena of Political Conflict, Halifax, Fernwood Publishing, 1993.

Smith, K., Environmental Hazards: Assessing Risk and Reducing Disaster, London/New York, Routledge, 1996.

Socolow, R., C. Andrews, F. Berkhout and V. Thomas, eds., Industrial Ecology and Global Change, Cambridge, UK, Cambridge University Press, 1994.

Steininger, K., "Reconciling Trade and Environment. Towards a Comparative Advantage for Long-Term Policy Goals," Ecological Economics, vol. 9, p. 23-42, 1994.

Tobin, J., The Tobin Tax on International Monetary Transactions, Canadian Centre for Policy Alternatives, September 1995.

Van der Stichele, M., Globalisation, Marginalisation, and the World Trade Organization, Amsterdam, The Transnational Institute, 1997.

Vilar, P., A History of Gold and Money, 1450-1920, London, NLB, 1976.

Ward, K., ed., Women Workers and Global Restructuring, Ithaca, NY, ILR Press, Cornell University, 1990. 